\title{
The Nigerian State and the Challenges of Rising Cases of Sexual Assault Among Nigerian Citizens
}

\author{
Oladimeji Sogo Osewa ${ }^{1}$, Ngozi Thelma Mohammed ${ }^{2}$, \& David Oluwatoba Alabi ${ }^{3}$ \\ ${ }^{1}$ Department of Political Science and Defence Studies, Nigerian Defence Academy, Kaduna \\ Nigeria. Email:osewa.oladimeji@gmail.com \\ ${ }^{2}$ Department of Political Science and Defence Studies, Nigerian Defence Academy, Kaduna \\ Nigeria. Email: ntmohammed@,nda.edu.ng \\ ${ }^{3}$ Department of Political Science and Defence Studies, Nigerian Defence Academy, Kaduna \\ Nigeria. Email: doalabi@,nda.edu.ng
}

Area/Section: Social Science.

Type of the Paper: Exploratory Research.

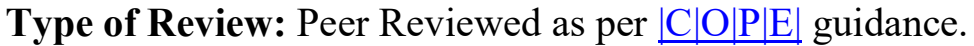

Indexed in: OpenAIRE.

DOI: $\underline{\text { http://doi.org/10.5281/zenodo.3997479. }}$.

Google Scholar Citation: IJMTS.

\section{How to Cite this Paper:}

Oladimeji Sogo Osewa, Ngozi Thelma Mohammed, \& David Oluwatoba Alabi. (2020). The Nigerian State and the Challenges of Rising Cases of Sexual Assault Among Nigerian Citizens. International Journal of Management, Technology, and Social Sciences (IJMTS), 5(2), 107-115. DOI: http://doi.org/10.5281/zenodo.3997479.

International Journal of Management, Technology, and Social Sciences (IJMTS)

A Refereed International Journal of Srinivas University, India.

(C) With Authors.

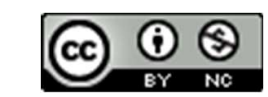

This work is licensed under a Creative Commons Attribution-Non-Commercial 4.0 International License subject to proper citation to the publication source of the work.

Disclaimer: The scholarly papers as reviewed and published by the Srinivas Publications (S.P.), India are the views and opinions of their respective authors and are not the views or opinions of the SP. The SP disclaims of any harm or loss caused due to the published content to any party. 


\title{
The Nigerian State and the Challenges of Rising Cases of Sexual Assault Among Nigerian Citizens
}

\author{
Oladimeji Sogo Osewa ${ }^{1}$, Ngozi Thelma Mohammed ${ }^{2}, \&$ David Oluwatoba Alabi $^{3}$ \\ ${ }^{1}$ Department of Political Science and Defence Studies, Nigerian Defence Academy, Kaduna \\ Nigeria. Email:osewa.oladimeji@gmail.com \\ ${ }^{2}$ Department of Political Science and Defence Studies, Nigerian Defence Academy, Kaduna \\ Nigeria. Email: ntmohammed@nda.edu.ng \\ ${ }^{3}$ Department of Political Science and Defence Studies, Nigerian Defence Academy, Kaduna \\ Nigeria. Email: doalabi@nda.edu.ng
}

\begin{abstract}
The social vices rape "has been around" for a very long time, it is as old as humankind. It has been experiencing in almost all the countries of the world. However, in a country like Nigeria, the issue of rape among the people had been on the rising rate these days as many babies, aged and teenagers had been raped to death. It is in view of the above challenges that this paper examined the causes, impact and solutions to the rising cases of rape in Nigeria. The paper adopted the relative deprivation theory to validate its arguments, while data are gathered through the secondary methods as data are retrieved from books, articles, newspapers and internet materials. This paper argued that the major causes of the rising cases of rape in Nigeria are youth's unemployment that is realized as a result of bad governance, and submit that good governance is the only lasting and perpetual solution to the rising cases of rape in Nigeria.
\end{abstract}

Keywords: Bad Governance, Rape, Youths unemployment, Ritualism, Deprivation, Good governance.

\section{INTRODUCTION :}

The phenomenon rape has been existing among human for a very long time. It is as old as human kind. It is a criminal and social vice that has been bedevilling the Nigerian State years back. However, it is very germane to note that the present-day rape is a new form of rape and a modern crime ravaging the society. Based on the fact that its motive differs from that of the primitive rape that is done only for fun, and to kill the perpetuators' sexual urge. This is different from the modern-day rape that is done for economic purposes e.g. money ritualism. Though both form of rape occurs simultaneously in Nigeria today. However, just about few years now the ridiculous act of rape cases among Nigerians has been drastically rising, as several cases of rape mostly among the Nigerian youths is being experienced in Nigeria. There are numerous cases of rape and gang rape in Nigeria, as the infamous ABSU gang rape being the most widely reported to the date despite the proliferation of social Medias, many cases go unreported (Okafor, 2013) [1]. Many more cases up till this moment have occurred in Nigeria. United Nations statistics on incidences of rape compiled from government sources showed that more than 250,000 cases of rape or attempted rape were reported by the police annually (Alao, 2018) [2]. The report covered 65 countries including Nigeria (Alao, 2018) [2]. In consonance with the above, although there is dearth of comprehensive data in Nigeria, however, information across the states shows that rape cases are on the increase (Izzi and Obinuchi, 2016) [3]. Even though the phenomenon rape has become a universal experience, as such cases has been accounted for world wide. It is important to note that rape is a global issue as it has been reported in almost all part of the world (Izzi and Obinuchi, 2016) [3].

However, it is necessary to note also that the menace rape among Nigerians is not just a natural phenomenon 
or a situation where citizens are naturally inclined to perpetuate such act, but it is an act that it causes could be traced significantly to bad governance. It could be traced to drug addiction and influence from bad companies in advanced countries of the world. Nevertheless, in Africa's and Nigeria in particular it is mostly motivated by youth's idleness (unemployment), drug addiction and bad companies. From young people, the effects of unemployment may be particularly scaring (Ezenwoke, 2016) [4]. This is because; it tempts or provokes the youths to resort to anti-social behaviors which are inimical to their communities (Ezenwoke, 2016) [4]. The high rate of youths unemployment and the need to survive at all cost has prompted Nigerian youths to engaging in many criminal ways of survival including ritualism that has given birth to the issue of babies, aged and girls raping, as those victims of rape sperm are being wiped with an handkerchief, handkerchief that is latter taken to the herbalist for money rituals. There is a concomitant relationship between bad governance and high rate of crime and poverty and vice-versa (Osewa, 2019) (5). A state where citizens are denied of their basic needs of lives including employment, citizens tend to engage in criminal activities to survive (Osewa, 2019) [5]. Those crimes mostly today include ritualism, and it is in order to address the above challenges that this paper examined the following, thus:

- Accessed the causes of the high rate of rape cases in Nigeria

- Accessed the impacts of rape on the victims of rape in Nigeria

- Examined the solutions to the high rate of rape cases in Nigeria.

\section{THEORETICAL FRAMEWORK :}

Relative Deprivation by Samuel Stauffer et al (1949) they propounded the theory Relative Deprivation in their sociological work, the American soldier. However, the theory had severally been applied in various scholarly works. Relative Deprivation explains the lack of resources to sustain the diet, lifestyle, activities and amenities that an individual or group are accustomed to or that are widely encouraged or approved in the society to which they belong. Measuring relative Deprivation allows an objective comparison between the situations of the individual or group compared to the rest of the society. Relative Deprivation may also be traced to the individual experience of discontent when being deprived of something to which one believed oneself to be entitled. It is a term used in social sciences to describe feelings of measure of economic, political, or social deprivation that are related rather than absolute (https://em.wikipedia.wiki >relativedeprivation) [6]. The deprivation that has bedevilled the Nigerian society, as Nigerian government had failed in their constitutional responsibility to give the basic needs of lives to her citizens especially employment which is supposed to be the rights and a free gift which all Nigerian citizens is supposed to be entitled to, being one of the constitutional duties of every government. Citizens seeing themselves as been denied of their basic needs of livelihoods when compare to citizens of other advanced countries that are enjoying this basic needs, and as Nigerian citizens believed to have been deprived of their economic, social and even political rights. This had led to frustration as the future of Nigerian citizens especially the youths had been bastardize thereby making Nigerian unemployed youths to find a way of survival through various criminal and evil channels such as cyber-crime (yahoo-yahoo), drug pushing, armed robbery, kidnapping and mostly ritualism that have given birth to the high rate of rape in the country. Rosatti and others argued that frustration and conflicts is the result of blocking someone or group toward achieving what they are entitled to (Rosatti et al 1990 in Gaya, 1999) [7]. Those women that are rape are being use for money rituals as their sperm are wiped with a handkerchief that is taken to a spiritualist for money rituals. Abraham Maslow emphasized on the importance of needs to workers, as workers will only work hard if those needs from the physiological need to the selfactualization is certified (Maslow, 1943) [8]. So also, are the importance of the basic needs of live to every country's citizenry and the deprivation of such needs will certainly leads to social vices (Crimes including rapping for ritualism).

\section{CONCEPTUAL SUBMISSIONS :}

\subsection{WHAT IS GOOD GOVERNANCE :}


As the name implies, good governance as to do with ensuring that government takes up its constitutional duties as expected, which has to do with giving the basic necessities of lives, and guaranteed welfare of all in the state. Secretary-General Kofi Annan argued that "Good governance is perhaps the single most important factor in eradicating poverty and promoting development". "Good governance has 8 major characteristics. It is participatory, consensus oriented, accountable, transparent, responsive, effective and efficient, equitable and inclusive and follows the rule of law. It assures that corruption is minimized, the views of minorities are taken into account and that the voices of the most vulnerable in society are heard in decision-making. It is also responsive to the present and future needs of society" (in Unescap, 2020) [9]. Even though there is no single or generally acceptable definition of the concept good governance however, good governance that is staged in accordance to the constitution and possesses characters such as transparency, accountability, respect for the rule of law and guarantees citizens of their freedom from want and freedom from fear really implies good governance. That is human security in its entire meanings.

\subsection{WHAT DOES RAPE IMPLIES :}

The phenomenon rape is not a new criminal act; it has been experienced world-wide. However, it is a devilish act frown at by human and even God. Nevertheless, it is the act of sexual assault in which men forces themselves in having sex with a woman against her agreement and submission. It is an act when exposes to the society, makes such lady loose her dignity, pride and respect in the society. It is a punishable offence under Nigerian law, as it causes psychological distress, and long-time stigmatization on the women raped. Patricia Easteal argued that "rape is the penetration of the mouth, vagina or anus by any part of the attacker's body or by an object used by the attacker, without the consent of the victim. He argued that rape requires physical force" (Easteal, 1992) [10]. The argument of Easteal signify that rape is not limited to force penetration of the vagina only, but it may include the forceful penetration of the anus and the mouth by the attacker.

\section{THE SYNERGY BETWEEN GOOD GOVERNANCE AND RAPE IN NIGERIA :}

Good governance as discuss earlier implies government by the consent of the law. It is the government that rules according to, or in accordance to the constitution of the state. Good governance is the governance that ensures the protection of all her citizens in all ramification of life, that is given the basic needs of lives to all her citizens especially education and employment that will liberate citizens mind and put food on the table of the citizenry. At any point in time if the government fails to do the above, then it resorts to crime in the society. It is the failure of Nigerian government to guarantee the above, as in the basic needs of lives that has led to the broke out of series of social vices such as armed and unarmed crime, including ritualism which most of the youths today now sees as the only way out of poverty ravaging them. It was the ritualism that gave birth to the devilish act of rape that is looming in Nigeria of today.

\section{WHAT ARE THE CAUSES OF THE RISING CASES OF RAPE IN NIGERIA :}

The causes of the rising cases of rape in Nigeria are numerous, as the menace of rape is not mono-causal. However, those causes are addressed below.

Bad Governance: The government of Nigeria has abysmally failed in their constitutional responsibilities, especially in the area of ensuring transparency, accountability, application of the rule of law and ensuring development and welfare of citizenry. Citizens of Nigeria have been deprived of their basic needs of lives, especially free education and employment, and the essential facilities which should be seen as citizens' rights and a free gift from the government, that which can enhances citizens livelihood and guarantee high standard of living. The deprivation of such had led to increase in poverty and the rate of crime as citizens especially the youths have resorted to crimes in order to survive. When people are not fully employed, they are bound to engage in different types of crimes as a survival strategy (Metu, at al. 2019) [11]. Crime such as cybercrime (yahoo-yahoo), kidnapping, armed robbery, terrorism, drug trafficking, area boys and ritualism that has given birth to the rising rate of rape cases as those victims of rape especially those babies are raped and used for money rituals in Nigeria. There is concomitant relationship between bad governance and increase in poverty 
and crime rate in a country and vice -versa (Osewa, 2019) [5].

Higher rate of youths submissiveness to ritualism in Nigeria: The present generation will make us recall the fact that majority of the youths in Nigeria had no brighter future due to the deprivation leveled on them by the failed government of Nigeria. Many had even concluded that this present generation is a wasted generation. Nevertheless, the present-day youths had been badly conscientized that, there had been higher rate of submissiveness to the devil as they seek monetary assistance from the devil that has in-turn demanded or requested for human blood, or sacrifices in return. Increase in devilish rituals explored by these youths to fund their lust has been brought to National attention (Nwanne and Anazia, 2019) [12]. This has led to vices such as rapping of babies, young girls, old age women and ladies, as their sperm and blood are used for money rituals. We have heard of the irritative act of eating human physics and the use of ladies' pant for money rituals. It is called yahoo plus in Nigeria.

Drug Addict: Still, one of the effects of bad governance is losing our able-bodied citizens especially youths to drug addiction. Many of those youths that is expected to be engaged are seen roaming the street. Many of them end up associating with bad allies that lured them into the bad act of indulging in drugs. Many of those youths after being under the influence, vision and spiritual direct control of high drug, and as rise as their libido become, they end up looking for a place to release these pressures which on many occasions had led them to rapping any girl that fall victim. Nevertheless, you found them perpetrating such act anywhere without minding how perfect the environment is, as they are being influenced by the drug. Adolescents are naturally less in control of their emotions and the use of alcohol may worsen the situation by reducing their ability to make rational decisions (Nwagu, 2016) [13]. Hence alcohol and other drugs of abuse such as Indian hemp increase adolescents risk taking behaviors especially with regards to their sexuality (Strunin and Hingson, 1992; Unachukwu and Nwankwo, 2003; in Nwagu, 2016) [13].

Lack of parental guidance, orientations and control: Charity begins at home. The primary agent of socialization to every child is the family. Parents and guidance have a lot to do in the life of every child, as they are the first contact of the child where the child emulates characters and behaviors from. Any child that lack the necessary moral training and orientation or control end up becoming street niggers with bad allies who teaches them bad and criminal act and lured them into criminal activities, and urge for wealthy fame which they seek through ritual channels, as they indulged in rape activities for money ritualism. According to Julie OkahDonli, Drector-General of the National Agency for the prohibition of trafficking in person, she attributed the cause of rape to Nigeria's socio-cultural climate that supports female subjugation which can lead to increase incidents of rape. She argued that "parental negligence and lack of proper training of male children; one sidedness in cultural orientation with excessive attention on the girl child are the causes of rape in Nigeria" (Julie, 2020) [14].

Indecent Dressing: The socio-cultural decadence in the Nigerian society of today which was emulated from the foreign countries e.g. countries of the west and Europe mostly in the area of dress has become the order of the day as most of Nigerian ladies now prefer to dress indecently as they exposes their body to the world to see. This immorality and lack of cultural orientations has also contributed immensely to the cause and high rate of rape cases in Nigeria. Even though it cannot be seen as a justification for the devilish act of rape. Nevertheless, it has contributed greatly in the rising rate of rape cases in Nigeria. Findings revealed that indecent dressing amongst other factors heavily contributed to the spread of rape in Nigeria (Akinade and Sulaiman, 2010) [15].

The Emergence of Coronavirus Pandemic in Nigeria: The out brake of Covid 19 pandemic is another factor that triggers the criminal act of rapping in Nigeria. Most of these street boys that use to visit hotels and chalet to enjoy funs with prostitutes were all caught in the nationwide lockdown, and the fact that all hotel and chalets has been closed down, and the fact that those street boys are used to constant sexual intercourse which they have been deprived of during this period of pandemic and lockdown, and which has now resort to rapping of any females that fall victim in the environment. Those street boys are always on the street with their active libido, and looking for any female ladies to kill their sexual urge. "\{Nearly a week into the 14 days initial lockdown of some part of Nigeria as part of measures to contain community transmission of the 
dreaded coronavirus pandemic, the shutdown may have triggered the rising cases of rape as two minors were reportedly violated by their neighbors last week" (Odita, 2020) [16].

\section{THE IMPACTS OF RAPE ON THE VICTIMS OF RAPE IN NIGERIA :}

The menace of rape in the society has become a great challenge and a threat bordering most citizens of Nigeria at present. However, such act has had overwhelming effects mostly on the victims of such act on one hand, while the effect of paying the price with imprisonment or death as the case may be is leveled on the perpetuators on the other hand too. Below are some of the impacts.

Stigmatization: On many occasions, the victims of such act (rape) mostly suffers. Stigmatization from the society, as her family and she or he is been bully and disrespected by the people. The victim also suffers psychological and post-traumatic effects as the victims found it difficult to put him or herself together and go on with his or her life. They tend to be depressed and suffer emotional imbalance for longer period. In the absence of proactive interventions, rape victims constantly relive the trauma associated with the past wrongs and shame suffered for which their communities are not internally equipped to deal with (Manni et al, 2018) [17].

Death of victims: The criminal act rape mostly leads to the death of the victims. While some victims are being killed after being raped, others tend to resort to poisoning themselves as they believe that they are no longer relevant to the society as the stigma will ever be on them. More death cases have been attached to rape cases in Nigeria. Example is the recent gang rapping and the killing of Uwaila in Benin, Edo State in June 2020 in Nigeria. Akinwotu submits that vera Uwaila Omozuwa, 22years old microbiology students, sought the quiet of her empty church in Benin city, southern Nigeria, as a place to study. Hours later she was raped and killed (Akinwotu, 2020) [18].

Contraction of infectious diseases: Most ladies raped after consulting physicians for test, discovers that they have been infected with dangerous and deadly diseases such as gonorrhea, staphylococcus, cephalous, HIV/AID etc. They mostly suffer the effect and the challenges of these diseases for many years thereby reducing the qualities of lives of those victims. Many rape victims have acquired HIV/AIDS and other sexually transmitted infections which can result in infertility (Muoghalu, 2012) [19].

Unwanted Pregnancy: Most of the victims of rape after test were made to know that they have been impregnated. Some had taken the risk of terminating the pregnancy, while others have given birth to fatherless and unwanted babies whom also suffers stigmatization till old age. Indeed, peters and Olowa (2010) [20] argued that rape result in trauma, sexually transmitted infection and potentially unwanted pregnancy which itself constitutes a traumatic experience.

Injustice in the court of law: Most of the victims of rape in Nigeria hardly get justice in the law court, as most of them are either not financially buoyant to prosecute the offendant by getting a good lawyer or because they are being threatened by the family of the offendant, or even the police as they are mostly advised by the police to withdrew the charges in order for their image not to be tarnished in the society. On the other hand, if the victims are strong enough financially and she eventually get justice, the offendant (rapist) get sentenced to either death or life imprisonment, thereby putting their family into shame and restlessness. It was reported that activists, who have campaigned for a stricter model that involves a comprehensive investigation, prosecution of offenders, and rehabilitation of victims, say that template leaves thousands of Nigeria's rape victims without much help (Yahaya, 2019) [21].

\section{THE LAWS ENACTED TO TACKLE THE MENACE OF RAPE IN NIGERIA: HOW ADEQUATE?}

Considering some laws promulgated to tackle the cases of rape in Nigeria, and the inadequacy of those laws which prompted Nigerians to call for the enactment of new laws that is potent enough to tackle and eradicated the rising rate of rape cases in Nigeria. The criminal and penal code off 1990 is the law guiding rape justice in Nigeria (in Yahaya, 2019) [21]. However, it is pertinent to note that this law is inadequate and deficiency as it defines rape as having unlawful canal knowledge of women or girl without her consent or with her consent if it is obtained by force or by means of intimidation. This definition is not all encompassing looking 
at the menace rape in it broader sense. The laws only emphasized on the fact that perpetuators of rape are men only and that woman only are the victims or against which the crime of rape is committed. The law does not also emphasize on anal or oral penetration as a method of rape. Nevertheless, it was against the above challenges and deficiency that the violence against person (prohibition) Act of 2015 (VAPPA) was enacted with the aims of checking sexual and gender base violence. Here, other method of rape such as anal sex, and gang rapping was included with 12years imprisonment far from the judge's discretion (Yahaya, 2019) [21]. The Nigerian law also provides in section 358 that the punishment for the offence of rape is life imprisonment. According to the section 6 of the criminal code Act, it states that the offence of rape is complete upon penetration (in Ewulum et al, 2014) [22]. It states further that unlawful carnal connection is one which takes place otherwise than between husband and wife.

At this juncture the argument of emphasizing against the fact that victims of rape are women only erupted here as many legal scholars emphasized on the possibilities of women rapping men, or a man being gang raped by women which was not included in the law, even though its cases are minimal in occurrence. However, despite all of the above laws, rape cases are still at it rising rates in Nigeria. These have given birth to the question of how adequate is those laws enacted to fight against the menace of rape in Nigeria. These therefor necessitate the need for the promulgation of more effective and potential laws to tackle the menace of rape in Nigeria.

\section{THE WAYS THROUGH WHICH THE MENACE OF RAPE COULD BE ERADICATED IN NIGERIA :}

The menace rape could be eradicated in Nigeria. Eradicating any forms of crime in the society is always not a challenge provided the government is ready to truly deal with such crime. In the case of Nigeria, the readiness of the government to sincerely wage wars against such crimes determines the quick eradication of such crime. The Nigerian governments are fun of curtailing issues, not treating or addressing it from the roots and these is why many national issues are seen to be lingering for too long. The fact that most of those crimes are perpetuated, or are motivated by bad governance, as government officials sometimes are the ones found in the forefront of aiding some of these crimes lingering in the society. For example, aiding political thugs, ritualism, homosexualism, etc. This most of the time makes it very difficult and impossible to eradicate most of those crimes which makes them linger for too long in the society. To eradicate the menace of rape in Nigeria, the causes of the menace need to be examined because there may be danger in neglecting the causes as the root causes will clearly signify the way to the lasting solution. Below are some of the solutions to the increasing cases of rape in Nigeria.

Good Governance: Bad governance that was seen as one of the major causes of the menace of rape in Nigeria by this paper, also in its opposite serves as one of the solutions to the menace of rape in Nigeria. The sincere truth is that there is a concomitant relationship between good governance and drastic reduction in poverty and crime rate and vice- versa. Nevertheless, until Nigerian government deemed it fit to give the basic necessities of life's especially employment and education to the teaming jobless Nigerian youths that has seek a means of economic survival through ritualism that has given birth to raping of babies, young girls and even the aged women's in which there sperms are wiped with handkerchief that are used for money rituals. If not, the menace may not be easily eradicated.

Adequate and Potential Laws should be Enacted: To fight against the menace of rape in Nigeria, it is the duty of the judiciary to promptly springs into actions in making new virile and strong laws that will stand differently firm on its own, if possible with a distinct court of law, specifically design to fight the act of rape and the menace of rape in the society. These laws must be draconian in nature with a severe deadly punishment coming with it to deal with the perpetuators of rape. For example, many Nigerians had been calling for quicker justice in the law courts on the cases of rape, as some Nigerians had even suggested the cutting of the penis of those men perpetuators. However, the author of this paper does not argue in support of such action as the cutting of perpetuator's penis may be repugnant to natural justice and fairness. But nevertheless, for the act of rape that claim lives of the victims, then, the perpetuators should also be sentenced 
to death, but if life is not lost, then, the life imprisonment penalty is adequate.

The Fight against Ritualism: The act of money ritualism that has given birth to the rising rate of rape in Nigeria needed to be tackled by the government. The aggrieved Nigerian unemployed youths of today have all being initiated in an occultist brotherhood through which they enrich themselves through money rituals. Many of those youths who initially engaged in cyber-crime (yahoo-yahoo) has turn to ritualism today, one that is today called yahoo plus, and has enhances the menace of rape in Nigeria.

Sexual Education: To address the issue from the root, the government should incorporate in the school syllabus, or if already exist in the syllabus makes it more compulsory, a subject that will teach sex education, and the danger of being raped and the severe punishment that is faced by the perpetuators, this which must be taught from primary to the university level in Nigeria will help a lot in eradicating the menace completely in the country.

Cost of Litigation to be taken by the government: The challenges of high cost of litigation faced by the victims of rape in court of law is another impediment to getting justice in the court as many victims could not afford the cost of prosecuting the perpetuators which makes the victims most of the time withdrew or advice to withdrew the charges that is against the perpetuators. Nevertheless, in order to ensure that perpetuators are charged and sentenced accordingly, and ensure that victims of rape get justice. The government must take responsibilities of bearing the cost of litigations in rape cases at the court of law in Nigeria, as these will go a long way in serving as deterrence to other Nigerians that may want to perpetuate such act.

Parental Training and Orientation: The first agent of socialization is the parents. Children tend to learn from and emulate the character or attitude of their parents. At that stage of a child's life, whatever the child learns from his or her parents usually stick to his or her brain as it reshapes his or her attitude and the way the child behaves as he or she grows up in the society. Nevertheless, a well train child will never indulge in the devilish act of ritualism or rape and vice- versa.

\section{CONCLUSION :}

The rising rate of rape in Nigeria today signify the failure of the government to economically manage her citizens, as citizens had been deprived of their economic livelihood which has resulted to the outbreak of numerous crimes including ritualism that had gave birth to the menace of modern rape in the society. This paper had examined the causes, effects and put forward workable solutions to tackle the rising rate of the menace of modern and primitive rape cases in Nigeria, and affirmed that the menace can be eradicated only if the government is truly ready to address the issues from the root, if not, the menace will only be curtail for a few period of time, as it will linger for longer period, and can cause too many damages mostly to the victims in the society.

\section{DEDICATION :}

This article is dedicated first to the Almighty God, to my late lovely mother Mrs. Racheal Alake Osewa and lastly to my caring sister Miss Olushola Osewa for her financial contributions to my academic life so far. I say a BIG thank you.

\section{REFERENCES :}

[1] Okofor, V. Amaka (2013). Nigeria has a Rape culture too. The guardian, Monday $14^{\text {th }}$ January. Retrieved from https://www.theguardian.com $>$ jan $\quad$ (Accessed $6^{\text {th }}$ June, 2020)

[2] Alao, O. Joseph (2018). An Examination of impact of rape on the victim and the socio-Development of Nigeria. Afro Asian Journal of Social Sciences, 9(3), 1-8.

[3] Izzi, O.M and OBINUCHI, C. (2016). The challenges of Rape victims in Nigeria and the way forward. The journal of Jurisprudence and contemporary issues, 8(2), 226-244.

[4] Ezenwoke, Godwin (2016). Unemployment and youths crimes in Nigeria (Acase study of Anambra State 2010-2015). Retrieved from https://www.academia.edu>unemployment (Accessed $6^{\text {th }}$ June, 2020) 
[5] Osewa, O.S. (2019). Terrorism in Nigeria: Causes, consequences and panacea. International Journal of Legal Studies, 2(6), 341-366.

[6] https://e.m.wikipedia.wiki>relativedeprivation (Accessed $8^{\text {th }}$ June, 2020)

[7] Gaya, S Best (1999). Introduction to peace and conflict study, UI Publisher, Ibadan Nigeria

[8] Maslow, A.H (1943). A theory of human motivation. Psychological Review, 50(4), 370-96. Retrieved from https://www.simplypsychology.org (Accessed $8^{\text {th }}$ June, 2020)

[9] Unescap (2020). What is good governance. Retrieved from https://www.unescap.org $>$ site $>$ files (Accessed $9^{\text {th }}$ June, 2020)

[10] Easteal, L. Patricia (1992). What is Rape. International journal of forensic sciences. 20(11), pp 1-12.

[11] Metu, M; Kalu, C; and Maduka, O. (2019). Analysis of crime rate and economic growth in Nigeria: The institutional challenges and way forward. Journal of Economic Studies, 15(1), 39-50.

[12] Nwanne, C and Anazia, D. (2019). Nigerian youths the scramble for quick wealth fame. Saturday Magazine. Retrieved from https://m.guardian.ng $>$ saturday-magazine (Accessed $10^{\text {th }}$ June, 2020)

[13] Nwagu, N. Evelyn (2016). Alcohol and drug usage, and adolescents sexual behavior in Nigeria. Health Promotion International, 31(2), 405-413.

[14] Julie, O. Donli (2020) "Lack of proper Traininmg for male children by parents, delay justice causing Rape increase in Nigeria". Sahara Reporters New York. Retrieved from www.saharareporters.com $>2020 / 06 / 03>$ lack (Accessed $9^{\text {th }}$ June, 2020)

[15] Akinade, E.A and Sulaiman, A.A. (2010). Socio-Legal Factors that Influence the perpetuation of rape in Nigeria. Procedia-Social and Behavioral Sciences, 5, 1760-1764.

[16] Odita, Sunday (2020). Lockdown triggers rise in Rape of minors, C.P warns. Retrieved from https://m.guardian.ng>news $>$ lockdown.. (Accessed $9^{\text {th }}$ June, 2020)

[17] Manni, I. Jenis and Babbage, Victor (2018). Northern Nigeria: Rape, Stigma and the unfolding story. Communications for the common good. Women Arise. Harper Hill Global. https://www.harperhill.global $>$ sg5nigeria (Accessed 14 ${ }^{\text {th }}$, June, 2020)

[18] Akinwolu, Emmannuel (2020). Rape and Mueder of student in church sparks outrage across Nigeria. The guardian. Retrieved from https://www.theguardian.com>june $>$ andrapeandmurder $\quad$ Accessed $9^{\text {th }}$ June, 2020)

[19] Muoghalu, O. Caroline (2012). Rape and women sexual health in Nigeria: The stark realities of being female in a patriarchal world. The African Anthropologist, 19(182), 33-41.

[20] Peters, O. and Olowa, O. (2010). Causes and incidence of Rape among middle aged and young adult in Lagos State, Nigeria. Research Journal of Biological Science, 5(10), 670-677.

[21] Yahaya, Halimah (2019). Nigeria's new Anti-Rape Law still can't help victims much. Premium times. Retrieved from https://www.premiumtimesng.com>news (Accessed $14^{\text {th }}$ June, 2020)

[22] Ewulum, E. B, Ezeanokwasa, Jude, and Nbanugo, O Obinna (2014). Rising cases of Rape offences in Nigeria: New measures to the rescue. Nawili,131-136. 